\title{
THE CONTESTED AUTHORITIES: Institution and Agency in the Enforcement of Sharia Law in Aceh, Indonesia
}

\author{
Sehat Ihsan Shadiqin* \& Eka Srimulyani \\ Universitas Islam Negeri Ar-Raniry \\ Jl. Kopelma Darussalam, Banda Aceh, Aceh, Indonesia, 23111 \\ e-mail: sehatihsan@ar-raniry.ac.id
}

\begin{abstract}
This article is aimed to explore the contested authorities in the enforcement of sharia law in Aceh. The existence of these contesting authorities could be observed in the qanun shari'a (the shari'a bylaws) formulation and implementation processes. In Aceh Province, this contestation is also further complicated by a wider contestation among formal and non-formal actors, representing pluralities of Aceh jurisprudence perspectives. Hence, the dynamic of sharia law products and its implementation in Aceh actually [re]presents a unique situation of how pluralities of actors could influence the Sharia Law formulation and its enforcement, and this is also mediated by the historical, political and cultural contexts. This research utilizes a qualitative approach, through a library research data collection which is also combined by few interviews. Generally, it seems that the authorities or agencies of both formal and nonformal institutions sometimes intersect, overlap and contest, which also complicate the production or of the incorporation of moderate Islamic thought.
\end{abstract}

Keywords: religious authority, institution, agency, Islam in Aceh, shariah law

* Corresponding Author 


\section{Introduction}

In 2001, based on Law No. 18 on Special Autonomy for Aceh, a province which is located in the westernmost part of Indonesia, were given the opportunity to implement the Islamic law as part of its formal law in its region. For the Central Government, this is one of the efforts in muffling the armed conflict that taken place after the falling of Suharto's Regime. ${ }^{1}$ Meanwhile, for some of the community in Aceh, this was the culmination of a prolonged aspiration in having the authority to implement the Islamic law that was alive until the beginning of Indonesian independent on $1945 .^{2}$ I frame these two-fold objectives as complementary to each other in order to have better understanding on the context behind of the implementation of Islamic law in Aceh within the contemporary and historical context.

There was a quite fascinating development emerges after the central government granted the authority to the governments of Aceh to apply shari'a law for Muslims in Aceh. There is a push-and-pull dynamic between granting the authority to implement Islamic Law, while keeping it in line with and not contradict with the national law as the foundation for all [derived] laws in Indonesian, including the bylaws. At the same time, as one of the Indonesian provinces, Aceh has a similar judicial apparatus, like any other provinces in Indonesia. Therefore in general it does not have a specific structure, in the form of special executive, judicative and legislative structure. Then the question is who is then having the authority as decision maker who could enforce the shari'a law in Aceh?

This article aims to answer the question by examining the existence of the authorities engaged in the implementation in Aceh both the state and non-state actors. Ichwan, through his article, categorized four authorities in implementing Islamic 
law in Aceh, namely, Shari'a state apparatuses which consist of Aceh's Consultative assembly (MPU), Mahkamah Syar'iyyah, The Sharia Office (Dinas Syariat Islam), Shari'a Police (wilayatul hisbah), and Islamic treasury Body (Baitul Mal); state apparatuses comprise Governor, Aceh's houses of representatives ( DPRA); political parties 'religious or secular', moslem scholar and Islamic movement organization. In his article, Ichwan focused on the authority held by MPU as a part in 'state apparatuses'. Unlike Ichwan's work, this article tries to explore how other authorities apart from MPU, are involved in the making and processing of shari'a law to be a formal law. Further on, I will explore how the authorities played out in three main domains of the shari'a law implementation such as; legislative's law, executive's law and society's law. My argument is the diversity of authority through implementation of Islamic law do not only produce the plurality of law as stated by Arskal ${ }^{4}$ but also as an opportunity to produce the concept/idea of moderate Islam, and its practices. Nevertheless, the same opportunity is also available for those actors who could possibly drag the concept and its practice towards the other end of exclusiveness and intolerance.

There has been some historical analysis that relates this bargaining of shari'a law implementation as a parcel of peace negotiation from Free Aceh Movement (Gerakan Aceh Merdeka, GAM). This will be followed by the discussion on the process of issuing Qanun (local bylaws) to provide a glimpse of how the shari'a actors (both state and non-state authority) exercise their authority. Lastly, some analysis on the contested space between conservative and moderate turn when the Qanun (Islamic bylaws) is drafted will be also provided. 


\section{Methodology}

This article describes the various sources of authority in Acehnese society, particularly in the implementation of Islamic law. The data of this article are based on a qualitative study. Data were obtained either through literature study as well as observation and interviews. The study of Islamic shariah by law in Aceh has been an important focus of researchers in the last decade. This gives us many perspectives to see the dynamics of religious authority in Aceh. We obtain and analyze relevant documents to explain religious authorities and how they relate to one another. In addition, research data was also obtained through observations of the socio-religious dynamics that occurred in Acehnese society, especially those related to the authority in drafting Sharia-based qanuns. Several interviews have been conducted with relevant informants to explain the phenomena that occur. The data of this study were analyzed with a sociological approach to understanding the prevailing system of this topic.

\section{Shari'a Law in Aceh: An Overview}

The current enforcement of the shari'a law in Aceh is inseparable with the existence of Islamic religion, its teachings and practices over the history of Aceh [Muslim] community. People believed that Islamic religion coming to Aceh three centuries after the Prophet Muhammad passed away. Azra explained that at least there were four theories regarding the earlier penetration of Islam to Aceh which named; Arabic theory, Persian theory, Gujarat theory and Sufism theory. ${ }^{5}$ Arabic theory referred to the argument that the traders from land of Arab and East Asia who voyaged to the Strait of Malacca and to west coast of Sumatran Island, they preached Islam through their trading activities. While Sufism theory talked about the fundamental 
role of Sufis who came and expanded the Islamic religion to the whole world. In this case, A. H. Johns believed that within the historical context of Aceh, where the indigenous religion were Hinduism and Buddhism, the expansion of Islamic religion occurred easily because these two religions share similar principal teachings with the Islamic religion, brought and practiced by Sufis. ${ }^{6}$ Similarly, Shihab also believed that sufism theory is more acceptable to explained the earlier penetration of Islam to the Archipelago. ${ }^{7}$

Islam has affected many ways of the socio-political lives of the people in Aceh over the time. The Pasai sultanate in Northern Aceh was the first Islamic kingdom in Archipelago. ${ }^{8}$ After this kingdom had already retreated, there was another kingdom called Aceh Darussalam in Aceh Besar in the XIV century emerged and had wide authority up to the peninsula of Malay. Islam became the most important religion in this region. As shown by Hadi ${ }^{9}$ this case can be seen how the Sultan of Aceh conducts a great party on every Islamic day doing prayer and kenduri (festivity). There have been some debates on the nature of sharia law enforcement during the sultanate period. Few scholars perceived that it was difficult to claim that all of the practices, law enforcement and such were totally Islamic law, many of them were made by the Sultan which known as common law. ${ }^{10}$ While local scholars tends to see Islam and state as unity and argued that the sultanate practice and relied on the shari'a law model of law enforcement in the mean time. ${ }^{11}$

The presence of Islam, and its law enforcement during the sultanate period used to be referred as the source of inspiration and drive behind the initiative the positivization of shari'a law in modern Aceh history. Several efforts to negotiate this specific right of Aceh to the central government of Jakarta has been done after the indenpendence of Indonesia from Dutch colonization, 
and after the revolution era. In 1953, Teungku Daud Bereueuh declared Aceh as part of Indonesia Islamic State (Negara Islam Indonesia, NII) which proclaimed by Kartosuwiryo in the West Java. ${ }^{12}$ This movement was also aimed to fight for the a special right for the shari'a law enforcement in Aceh. ${ }^{13}$ Although, the movement surrended and reconciled, nevertheless it is believed that the spirit for the shari's lawa enforcement among some groups of community in Aceh did no totally disappear. Although, the GAM 'derived' from the DI/TII of Beureueuh's movement, Hasan Tiro the founded of GAM seemed to concern more on the aspect and natural resources compared to his concern on the issues of Islamic law for Aceh. ${ }^{14}$

When Suharto stepped down in May 1998, Indonesia underwent the new history, known as Era Reformasi. The moment marked by the shifting of power from Suharto to the his vice president B. J. Habibie. During B. J. Habibie period, the struggle towards separatism strongly emerged such as in Timor Leste, Papua and Aceh. The policy of Habibie by giving the option of referendum to the province of Timur Leste has also encouraged the similar proposal from other area like Aceh. Meanwhile, the armed conflict in the mean time escalated and extended to wider areas of Aceh, that created a new phases of conflict. ${ }^{15}$ This momentum was used by GAM to fight for the independence of Aceh as a new state. ${ }^{16}$ This movement has made Aceh as the centel of armed conflict between GAM and the Government of Indonesian. Violence, violation of human rights, and life seemed living in horror. ${ }^{17}$ In the beginning, the Government of Indonesia tended to overcome through military force but this policy was considered to bring negative impact toward the society of Aceh. Therefore, In 2000, dialogue became an important instrument to the armed conflict. ${ }^{18}$ 
One of the persuasive approaches in overcoming the conflict was a special autonomy for Aceh province. ${ }^{19}$ One of the specialties of this constitution is the right for positivization of the sharia law. Initially, Jakarta resumed that rebellion of GAM similar to movement of Darul Islam in 1953. Few argued that it was the bargain proposed by GAM. Seemingly, this assumption was incorrect since the aim of GAM movement was not solely about independence but there were some other factors as well. ${ }^{20}$ The fact that Aceh gained a special right for sharia law enforcement did not solve the problem or made the armed conflict end. It was in August 2005, The Memorandum of Understanding (MoU) or the peace agreement was signed by both conflicting parties of Free Aceh Movement and the The Government of Indoensia. ${ }^{21}$ Nevertheless, the policy of the government to permit the implementation of Islamic law in Aceh are still practicing hitherto.

\section{Results and Discussion}

\section{The Governance of the Shari'a Regional Regulation}

Although Islam has become part of the society of Aceh's life but implementing their own law that should be in line with national law is not easy thing. ${ }^{22}$ After UU 2001, No. 18 has established, the government of Aceh conducted many important meetings to discuss the strategies for the sharia law enforcement, such as the interpretation or the perspective to be used for its regulations through the products of the bylaws. On the one side, they want to apply shari'a law kâffah (totally), whereas on the other side, the legal documents that is ready to be used for that purpose in modern and natio-state contexts like Indonesia are not yet available. In this situation there are two things considered as important to be prepared namely, the product/ material of the law and its governing institution. 
Soon after Undang Undang (act) No 182001 about the special autonomy, the Aceh province drafted several bylaws to regulate several aspects of Muslim's life in Aceh. The word 'perda (Peraturan Daerah/bylaws)' in The Aceh context of shari'a law are known as "qanun". The first step for the implementation of the shari'a law is by issuing the five Islamic bylaws. ${ }^{23}$ The first qanun was about the judiciary, namely shari'a court that handle the offenders of shari'a law. In the bylaws or Qanun of Aceh no.10, 2002 on Islamic sharia court was mentioned that sharia court has the authority to examine and to decide the cases related to; (a) ahwal al-syakhsiyah (famiy law), (b) mu'amalah (social aspects) dan (c) jinayah (crimne). The court was established for the purpose of shari'a law enforcement, which does not exist in other places of Indonesia. There are several other qanuns such as Qanun No. 112002 on shari'a law enforcement on worship symbols of Islam. Qanun No. 12, 2002, on alcohol consumption, and Qanun No. 13 2002, on gambling (maisir), and Qanun No. 14, 2002, on adultery (khalwat). ${ }^{24}$

Seeing the time of making, qanuns above are clearly made in a hurry, therefore some ideal process in making it was denied. For instance, academic study that should be done within all the process of making regional regulation did not studied from an academic aspect well. Muhammad Yus, Head of DPRD at that time impressed that the process of making qanun conducted in several meetings that involving stakeholders and some scholars from Islamic state university of Ar-Raniry. The Ulama Council od Aceh (Indonesia: Majelis Permusyawaratan Ulama, MPU) who drafted the qanun due to the time constraint and the tight deadline, had no adequate time to do some preliminary study or research on the aspect of law that is projected to be drafted on to the qanun, everything done fastly. Nevertheless, they acknowledged that MPU contributed significantly to the substance 
of the qanun before it is being discussed in the Aceh's Assembly representative (DPR), and issued accordingly. ${ }^{25}$

As discussed above, MPU does not have the authority in issuing the shari'a bylaws in Aceh. In this regards, the authority is belongs to the Aceh's assembly representatives. The MPU only contributed in the first draft of the qanun. Initially the organization like MPU is not dissimilar to the institution of MUI (Indonesian Ulama Council) exists at the national level and in all other provincial and district governments across Indonesia. What has made MPU in Aceh have more authority is the mandate from the Qanun No. 45, 2001 in which mentioned that MPU Aceh is one of the legal government organizations and has the same right with regional education council (Majelis Pendidikan Daerah, MPD). Since that MPU differed from MUI in other part of Indonesia, they can recruited stated civil apparatus that work for the office of MPU and they receive salary from the state. The members of MPU itself also receive regular salaries from the government.

Except MPU, the government of Aceh also established The Office of Sharia Law based on the mandate from the Qanun No. 33, 2001. ${ }^{26}$ Unlike the MPU, The shari'a office manages a number of administrative works related to the implementation of the shari'a law in Aceh. The office focuses on introducing the shari'a law through its official publications of books and brochures. Moreover the office also conducted some capacity building programs to enhance the skill of the preachers (muballigh), and send the specific groups of the preachers to the border areas of Aceh and North Sumatera that are considered as liable for the Christianization movement. In its earlier establishment, this office has the structure of the civil service policies, namely Wilayatul Hisbah (WH), which is different from the regular civil service police, members of $\mathrm{WH}$ is only responsible for 
overseeing the implementation of Shariah bylaws in Aceh. Nevertheless, due to some technical problems related to the salary, official rank and such, nowadays, WH institution is under the control of the civil service police unit (Satpol PP).

The already issued qanun was not adequate to the complexity of shari'a law enforcement in Aceh. Besides, from time to time, the idea to have better improvement and revision of the existing qanuns also emerged. One of the dilemmatic positions is that if the qanun was made separately for all of the matters, then Aceh might have so many qanun in its governance systems. In 2012, the discussion on the qanun that regulate many aspect of Muslim's life or namely penal codes has started, which then known as Qanun Jinayah (Jinayah Islamic bylaws). The process of drafting and discussing the qanun within the Aceh assembly system took place many years and was still unfinished until two year after. By the end of 2015, the Qanun Jinayah was then issued, and effectively started to be enforced in 2016. ${ }^{27}$ By the presence of the Qanun Jinayah, thus other qanuns previously are inoperative. Form the other sides, Qanun Jinayah also caused protests and critics from some groups of society. Human right's activist perceived the Qanun as has denied many aspects of human freedom and violence that performed through caning. ${ }^{28}$ Albeit some local scholars said vice versa. ${ }^{29}$ Likewise, women activist stated that Qanun Jinayah and other qanuns are very discriminative toward them. ${ }^{30}$ The same things is also felt by the minority of religious community (non-Islam), to them the Qanun Jinayah could produce some possible intolerants' attitude within society toward different believers. ${ }^{31}$

Apart from the institutions mentioned above, few instructions or referred as the sharia law enforcement are also regulate by the district level government. Based on the shari'a law arguments, they made written regulations that regulate various public activities 
which are supposed to be in line with Islamic Shariah. In 2010, West Aceh's regent, Ramli MS made a regulation called regent regulation (Indonesia; Peraturan Bupati) about the prohibition of wearing trousers and obligation of wearing skirt for women in his region. This regulation is known as regent regulation of skirt (perbub rok). In several months later, the same thing was done by Regent Gade Salam from Pidie Jaya Regency. In 2014, the Lhokseumawe's Major where his background is from GAM produced regulation about prohibition for women to sit astride when riding motorcycle. ${ }^{32}$ Astride on motorcycle disobeyed the cultural and tradition of Aceh and do not based on Islamic shariah. In 2018, Aceh Besar's Regent required a flight attendant who came to Aceh wearing a veil. He said that this regulation is aimed to respect the law that applied in Aceh. The newest case was the policy of Bireun's regent to forbid man and women joined together during the coffee time in cafés unless they are family relationships.

\section{Religious Organizations and the Public Piety}

The second part of authorities who were/are engaged in the sharia' law enforcement Aceh is from non-government organizations/ institutions. They are a community or individuals who are actively involved in various activities and religious movements in Aceh. At least, there are three religious organizations hitherto that always supposed belong to this movement, namely Ulama Dayah, religious organization and Islamic trans-national movement that came and developed in Aceh, more especially after the 2004 when the earthquake and tsunami hit Aceh, and has made Aceh received wider humanitarian assistance all around the world and made this are which was closed before, since then being opened widely to receive many people and organizations, including the trans-national organizations. 
Dayah or traditional Islamic boarding school has a significant history in the development of Islam in the archipelago. The dayah which is known widely as pesantren in Indonesia not only focuses on the learning of the Islamic teaching, but also through its actors has contributed socially, and politically to the nation. In Aceh, the actors from dayah background, known as "teungku", although in some cases the name attributed to them may varied such as 'waled', 'abu', 'abuya' and such. The ulama from dayah institution is referred as "teungku dayah", and they have specific organizations namely Association of Ulama Dayah Aceh (Indonesian; Himpunan Ulama Dayah Aceh, HUDA) that established 1998 to respond referendum demand that voiced by a group of students in Aceh. Since then, HUDA become the most active organization and involved in government's policy. Secondly, the Council of Nanggroe Aceh Ulama (Indonesian; Majelis ulama nanggroe Aceh, MUNA). This organization belongs to the ulama of GAM before they signed MoU in 2005. Finally, Inshafuddin, it is an organization of Ulama where its position is outside of MPU. In Inshafuddin, beside Ulama of dayah, there are also some intellectuals from the State Islamic University of Ar-Raniry Banda Aceh. Specially for the students, the dayah has the organization namely RTA (Rabithat Taliban Aceh), the association of Aceh dayah students. All of those organizations took specific positions and contributions in the discourse and practice of the sharia law enforcement in Aceh, but they are not state-agents like MPU, or the Shari'a office, discussed previously. Most of the teungku are male religious leaders, nevertheless, there are also few female religious leaders in Aceh community ${ }^{33}$.

Like kiyai (religious leaders) in Java, most of teungku in Aceh have a close relationship or connection to the bureaucracy and the political actors. From the general election in districts to choice a regent, to president election, they are active to voice 
of aspiration toward certain candidates. Some actors campaigned for their candidate, albeit many others became passive proponents. On other sides, politicians wielded tengku of dayah as a figure who are able to attract many people through their charisma within the society. ${ }^{34}$ Some teungku became part of the authority by becoming political official in parliament. But sometimes political option made people do not see teungku as ulama figure except for as political figurei. ${ }^{35}$

The close relation of teungku with authority is utilized to wield and extend their mission to wider community through the agency of the government or the bureaucracy. Generally, the society of Aceh has three types of religious views, Fauzi called tripolar typology, they are exclusivism polar, inclusivism polar and pluralism polar. ${ }^{36}$ Teungku dayah is included in the first view that is exclusivism polar. They belong to mazhab of Syâfi'i, they also called themselves as ahlussunnah waljamâ'ah. Ahlusunnah waljamâ'ah interpreted by implementing Islamic principles within the mazhab of Syafi'i which taught in dayah. Ulama of dayah against religious practices that different from them. In the beginning, this reaction was conducted only verbally such as through the religious congregation and such.

Under the influence of dayah, there were some organizations of students that conducted the movement, and they considered it as the effort to ensure and enhance the shari'a law enforcement in Aceh. These organizations are sporadic and do not concentrate within one particular organization. Their actions are often concerning razia (raid) targeted those whose dress code (especially women) are not in line with the principles regulated in the qanun. Besides that, they also conducted the razia around tourism places that are considered to have cases of violation against the sharia law, such as the unmarried couple who mixed or intermingled together in the area. This kind of raid usually does not engage 
the government again, it is more spontaneous and not regular, for them this is the representation of their efforts and intention to ensure the shari'a law enforcement in Aceh.

Qanun Jinayah mandated the Mahkamah Shariah (shari'a court) the authority and responsibility to adjudicate and to decide the status of Qanun's contravention committed. In general, people sometimes did that working in the name of customary law. In many cases in Aceh, for instance, a couple who committed mesum (pre-adultery), will be arrested and punished in various ways. Such as watered by dirty water, heated and asked to pay the customary law. This financial penalty is sometimes used for the expenses of the kenduri (feast) for few social groups of the society as the symbols of reconciliation. The authority held by the cultural institution (lembaga adat) to adjudicate misdemeanor, regulated in Qanun No. 9 and 10, 2001. ${ }^{37}$

\section{The Plurality of Religious Authority: Between “Conservative Turn" And The Moderate Islam}

By seeing various dynamics of shari'a law enforcement there are two things that may happen there; Firstly, the possible conservative turn manifested in the drafting of the qanun and how it is practiced. Secondly, the emerging of Islamic moderate attitude that embraces tolerance and non-violent attitude. These two things have similarity, albeit conservative turn is more dominant. This thing can be observed within two main aspects, namely the strengthened attitude of the Islamic Orthodox community and the public discussion that is opened for the process of qanun drafting.

Some religious practices in Aceh recently are claimed to have some inclination toward intolerance and violence in religious practice. One of the claim is based some event such as the anti- 
Wahabi movement of group of dayah and students who want to impose "sole Mazhab" in Aceh. This effort is often conducted through verbal assault, such as talk and social media. This case was also done by the effort to ensure that few mosques, especially the great mosque of Baiturrahman in the capital to apply some characteristics that is believed as principles in their affiliated sects or organizations.

The penetration of religious communities/groups through the trans-national organizations to Aceh after Tsunami has affected the attitude or behaviour, including the influence of the Islamic political party in parliament. Their strategic political position has enabled and granted them special authority to influence the policies of the shari'a law enforcement especially at the stage of policy making through the qanun drafting process. Throughout the political dynamics, especially during the political campaign sometimes also include the notions of shari'a law as part of their political commitments to attract their audiences/ voters. Their political commitment include the promises to produce regulations such as bylaws that represent Islam as the rahmatan lil âlamîn (that brings the betterment for all creatures). Potentially, the opportunity with the plurality of authorities to engage in the process would allow not only the conservative turn, but also the possibility to ensure the moderate ones. The process of qanun drafting indeed also have spaces available for those who are having the moderate perspectives, and promoting the moderate Islam. More importantly as the product of the regulation and policy making, the qanun is Aceh is not permanently fixed and unchanged, but could change and revised according to the need and the situation and again will follow the specific steps for this revision purposes. The process could start from the engagement of scholars and researchers to conduct a serious academic review before the process of qanun drafting. Interestingly 
the head or leader of those authorities such as MPU and Shari'a law office came from university background, which could make this process more possible.

\section{Conclusion}

The research suggests that the authority for the sharia law implementation in Aceh distributed, not hegemonized by a single agent or institution/office. Formally, the shari'a law in Aceh could be referred to the Qanun Jinayah. In practice, qanun is not the only/single reference for the implementation of the shari'a law in Aceh. Some other policies of the regents in some district in Aceh also colour the shari'a law implementations, even the controversial ones. In the other cases, some communal or social initiatives or interpretation in responding to the violations of shari'a law in the community is also considered as part of the spirit for the shari'a law implementation/practices. With this plurality, it leaves the shari'a law difficult to be measured accordingly. On the other hand, this space is used by several actors who have authority in society to show and exercise their authority. That authority in one case can be jogged, but in the other can be contested. The process of shari'a law drafting has involved a number of people, and engaged few organizations, institutions, office in different form and level of authority. This authority with some space available could produce the moderate version of shari'a law interpretation as well as the other way around.

\section{References}

Afrianty, Dina. Women and Sharia Law in Northern Indonesia: Local Women's NGOs and the Reform of Islamic Law in Aceh, 2015. https://doi.org/10.4324/9781315744568. 
Alamsyah, Andi Rahman, and Vedi R. Hadiz. "Three Islamist Generations, One Islamic State: The Darul Islam Movement and Indonesian Social Transformation." Critical Asian Studies 49, no. 1 (2017). https://doi.org/10.1080/14672715.2016.1260887.

Alfian, Ibrahim. Aceh and The Holy War (Prang Sabil). Verandah of Violence, The Background to The Aceh Problem, 2006.

Amirul Hadi. Islam and State in Sumatra: A Study of SeventeenthCentury Aceh. Leiden: Brill, 2004.

Amsori, Amsori, and Jailani Jailani. "Legislasi Qanun Jinayat Aceh dalam Sistem Hukum Nasional." Ar Raniry: International Journal of Islamic Studies 4, no. 2 (2018). https://doi.org/ 10.20859/jar.v4i2.138.

Anshori, Mohammad Hasan. "Linking Identity to Collective Action: Islam, History and Ethnicity in the Aceh Conflict." Studia Islamika 19, no. 1 (2012). https://doi.org/10.15408/ sdi.v19i1.368.

Ansor, Muhammad, Ismail Fahmi Arrauf, and Yaser Amri. "Under The Shadow of Sharia: Christian Muslim Relations from Acehnese Christian Experience." KOMUNITAS: International Journal of Indonesian Society and Culture 8, no. 1 (2016). https://doi.org/10.15294/komunitas.v8i1.4966.

Aspinall, Edward. "From Islamism to Nationalism in Aceh, Indonesia." Nations and Nationalism, 2007. https://doi.org/ 10.1111/j.1469-8129.2007.00277.x.

— . "Separatism in Aceh: From Social Rebellion to Political Movement." Social Activism in Southeast Asia, 2012. https:/ /doi.org/10.4324/9780203100233.

Aspinall, Edward, and Harold Crouch. The Aceh Peace Process: Why It Failed. Policy Studies. Washington: the East-West Center Washington, 2003. https://sci-hub.tw/https:// scholarspace.manoa.hawaii.edu/handle/10125/3503\%0Ahttps:/ /scholarspace.manoa.hawaii.edu/bitstream/10125/3503/1/ PS001.pdf. 
Avonious, Leena, and Sehat Ihsan Shadiqin. Adat Dalam Dinamika Politik Aceh. Banda Aceh: ARTI-ICAIOS, 2011.

Azra, Aryumardi. Jaringan Ulama Timur Tengah Dan Kepulauan Nusantara Abad XVII \& XVIII Akar Pembaharuan Islam Indonesia. Jakarta: Pranada Media, 2005.

Barter, Shane Joshua. "Resources, Religion, Rebellion: The Sources and Lessons of Acehnese Separatism." Small Wars and Insurgencies 19, no. 1 (2008). https://doi.org/10.1080/09592310801905769.

Bustamam-Ahmad, Kamaruzzaman. "The Application of Islamic Law in Indonesia: The Case Study of Aceh.” Journal of Indonesian Islam 1, no. 1 (2007). https://doi.org/10.15642/ JIIS.2007.1.1.135-180.

Chambert-Loir, Henri. "Islamic Law in 17th Century Aceh." Archipel, no. 94 (2017). https://doi.org/10.4000/archipel.444.

Danial, Danial. "Qanun Jinayah Aceh Dan Perlindungan HAM (Kajian Yuridis-Filosofis).” Al-Manahij:Jurnal Kajian Hukum Islam 6, no. 1 (1970). https://doi.org/10.24090/mnh.v6i1.590.

Fauzi, Fauzi. "The Interactions of Madzhabs in Aceh: The Tripolar Typology.” MIQOT:Jurnal Ilmu-Ilmu Keislaman 41, no. 1 (2017). https://doi.org/10.30821/miqot.v41i1.327.

Feith, Pieter. "The Aceh Peace Process: Nothing Less than Success." Defense, 2006.

Formichi, Chiara. "Pan-Islam and Religious Nationalism: The Case of Kartosuwiryo and Negara Islam Indonesia.” Indonesia, no. 90 (2010).

Gallop, Annabel Teh. "Gold, Silver and Lapis Lazuli: Royal Letters from Aceh in the 17th Century." First International Conference of Aceh Indian Ocean Studies 1998, no. March 1998 (2007).

Gayatri, Irine Hiraswari. "Dynamics of Village Institution: The Gampong under Aceh ÿs Special.” Journal of Indonesian Social Sciences and Humanities 2 (2018). https://doi.org/ 10.14203/jissh.v2i0.33. 
Grayman, Jesse Hession, Mary Jo Delvecchio Good, and Byron J. Good. "Conflict Nightmares and Trauma in Aceh." Culture, Medicine and Psychiatry 33, no. 2 (2009). https://doi.org/ 10.1007/s11013-009-9132-8.

Human Rights Watch. "Aceh Under Martial Law: Inside the Secret War.” Human Rights 15, no. 10 (2003).

Ichwan, Moch Nur. "Official Ulema and the Politics of ReIslamization: The Majelis Permusyawaratan Ulama, Sharatization and Contested Authority in Post-New Order Aceh." Journal of Islamic Studies 22, no. 2 (2011). https://doi.org/10.1093/ jis/etr026.

—. "The Politics of Shariatization: Central Governmental and Regional Discourses of Sharia Implementation in Aceh." In Islamic Law in Contemporary Indonesia: Ideas and Institutions, edited by Michael Feener and Mark Cammack, 193-215. Boston: Islamic Legal Studies Program, Harvard University Press, 2007.

Ikramatoun, Siti, Firdaus Mirza Nusuary, and Khairul Amin. "GAM and Social Transformation, from A Rebellion into A Political Movement." Proceedings of the 1st Aceh Global Conference (AGC 2018), 2019. https://doi.org/10.2991/agc18.2019.35.

Jafar, M. "Legitimasi Hukum Pemberlakuan Syari'at Islam Di Aceh: Tinjauan Yuridis, Sosiologis Dan Filosofis." Ulumuna 19, no. 1 (June 29, 2015): 59-78. https://doi.org/10.20414/ ujis.v19i1.1250.

Johns, Anthony H. "Sufism in Southeast Asia: Reflections and Reconsiderations." Journal of Southeast Asian Studies 26, no. 1 (1995). https://doi.org/10.1017/S0022463400010560.

Kamaruzzaman, Kamaruzzaman. "Relasi Islam Dan Politik Dalam Sejarah Politik Aceh Abad 16-17." Al-Tahrir: Jurnal Pemikiran Islam 16, no. 2(2016). https://doi.org/10.21154/al-tahrir.v16i2.494. 
Kingsbury, Damien. "The Free Aceh Movement: Islam and Democratisation." Journal of Contemporary Asia 37, no. 2 (2007). https://doi.org/10.1080/00472330701253759.

"Konsepsi Pidana Hudud Dalam Qanun Jinayat Aceh-Indonesia Dan Brunei Darussalam.” Kanun: Jurnal Ilmu Hukum 19, no. 1 (2017). https://doi.org/10.24815/kanun.v19i1.6670.

Lambourn, Elizabeth. "The Formation of the Batu Aceh Tradition in Fifteenth-Century Samudera-Pasai." Indonesia and the Malay World 32, no. 93 (2004). https://doi.org/10.1080/ 1363981042000320143.

Makin, Al. "Islamic Acehnese Identity, Sharia, and Christianization Rumor: A Study of the Narratives of the Attack on the Bethel Church in Penauyong Banda Aceh." Journal of Indonesian Islam 10, no. 1 (2016). https://doi.org/10.15642/ JIIS.2016.10.1.1-36.

McGibbon, Rodd. "Local Leadership and the Aceh Conflict." In Verandah of Violence: The Background to the Aceh Problem, 2006.

Milallos, Ma Theresa R. "Muslim Veil as Politics: Political Autonomy, Women and Syariah Islam in Aceh." Contemporary Islam 1, no. 3 (2007). https://doi.org/10.1007/s11562-007-0028-5.

Miller, Michelle Ann. Rebellion and Reform in Indonesia:Jakarta's Security and Autonomy Policies in Aceh, 2008. https:// doi.org/10.4324/9780203888193.

—-. "What's Special about Special Autonomy in Aceh?" Verandah of Violence: The Background to the Aceh Problem, no. November (2006).

Morfit, Michael. "The Road to Helsinki: The Aceh Agreement and Indonesia's Democratic Development." International Negotiation 12, no. 1 (2007). https://doi.org/10.1163/ $138234007 X 191939$.

Nirzalin Armia. "Teungku Dayah Dan Kekuasaan Panoptik." Substantia 16, no. 1 (2014). 
Nirzalin, Nirzalin. "Islamic Shari'a Politics and Teungku Dayah's Political Authority Crisis in Aceh." Journal of Government and Politics 3, no. 2 (August 1, 2012): 211-34. https:// doi.org/10.18196/jgp.2012.0012.

Nurdin, Abidin. "Reposisi Peran Ulama Dalam Penerapan Syariat Islam di Aceh.” Al-Qalam 18, no. 1 (2016). https://doi.org/ 10.31969/alq.v18i1.244.

Rahman, Bobby. "Pro Kontra Rancangan Peraturan Daerah Llhokseumawe tentang Larangan Duduk Secara Mengangkang Bagi Perempuan di Sepeda Motor." Jurnal Ilmu Politik Dan Komunikasi 3, no. 1 (2013).

Salim, Arskal. “'Sharia from below' in Aceh (1930s-1960s): Islamic Identity and the Right to Self determination with Comparative Reference to the Moro Islamic Liberation Front (MILF).” Indonesia and the Malay World 32, no. 92 (March 31, 2004): 80-99. https://doi.org/10.1080/1363981042000263471.

Salim, Arskal. Challenging the Secular State: The Islamization of Law in Modern Indonesia, 2008. https://doi.org/10.5860/ choice.46-6446.

Schulze, Kirsten. "The Free Aceh Movement (GAM): Anatomy of a Separatist Organization.” Policy Studies, no. 2 (2004).

Shihab, Alwi. Islam Sufistik: Islam Pertama Dan Pengaruhnya Hingga Kini Di Indonesia. Bandung: Mizan Pustaka, 2001.

Siregar, Hasnil Basri. " Islamic Law in a National Legal System: A Study on the Implementation of Shari'ah in Aceh, Indonesia." Asian Journal of Comparative Law 3 (2008). https://doi.org/ $10.1017 / \mathrm{s} 2194607800000156$.

Soebardi, S. "Kartosuwiryo and the Darul Islam Rebellion in Indonesia." Journal of Southeast Asian Studies 14, no. 1 (1983). https://doi.org/10.1017/S0022463400009024.

Srimulyani, Eka. "Gender in Contemporary Acehnese Dayah: Moving beyond Docile Agency?" In Gender and Power In 
Indonesian Islam: Leaders, Feminists, Sufis and Pesantren Selves, 2013. https://doi.org/10.4324/9780203797518.

Stange, Gunnar, and Roman Patock. "From Rebels to Rulers and Legislators: The Political Transformation of the Free Aceh Movement (GAM) in Indonesia." Southeast Asian Studies 29, no. 1 (2010): 95-120.

Utriza, Ayang. "The Implementation of Sharia in Aceh as Based on the Code Extant in the Sultanate of Aceh from 15161688." Studia Islamika: Indonesian Journal for Islamic Studies 14, no. 3 (2007).

Zarinebaf, Fariba. Policing Morality: Abuses in the Application of Sharia in Aceh, Indonesia. Living in the Ottoman Realm, 2016. 


\section{Endnotes:}

${ }^{1}$ Damien Kingsbury, "The Free Aceh Movement: Islam and Democratisation," Journal of Contemporary Asia 37, no. 2 (2007), https://doi.org/10.1080/00472330701253759; Edward Aspinall, "From Islamism to Nationalism in Aceh, Indonesia," Nations and Nationalism, 2007, https://doi.org/10.1111/j.1469-8129.2007.00277.x.

2 Arskal Salim, “'Sharia from below' in Aceh (1930s-1960s): Islamic Identity and the Right to Self determination with Comparative Reference to the Moro Islamic Liberation Front (MILF)," Indonesia and the Malay World 32, no. 92 (March 31, 2004): 80-99, https://doi.org/10.1080/1363981042000263471.

${ }^{3}$ Moch Nur Ichwan, "Official Ulema and the Politics of Re-Islamization: The Majelis Permusyawaratan Ulama, Sharatization and Contested Authority in PostNew Order Aceh," Journal of Islamic Studies 22, no. 2 (2011), https://doi.org/10.1093/ jis/etr026.

${ }^{4}$ Arskal Salim, Challenging the Secular State: The Islamization of Law in Modern Indonesia, Challenging The Secular State: The Islamization of Law in Modern Indonesia, 2008, https://doi.org/10.5860/choice.46-6446.

${ }^{5}$ Aryumardi Azra, Jaringan Ulama Timur Tengah Dan Kepulauan Nusantara Abad XVII \& XVIII Akar Pembaharuan Islam Indonesia (Jakarta: Pranada Media, 2005).

${ }^{6}$ Anthony H. Johns, "Sufism in Southeast Asia: Reflections and Reconsiderations," Journal of Southeast Asian Studies 26, no. 1 (1995), https://doi.org/10.1017/S0022463400010560.

${ }^{7}$ Alwi Shihab, Islam Sufistik: Islam Pertama Dan Pengaruhnya Hingga Kini Di Indonesia (Bandung: Mizan Pustaka, 2001).

${ }^{8}$ Elizabeth Lambourn, "The Formation of the Batu Aceh Tradition in FifteenthCentury Samudera-Pasai," Indonesia and the Malay World 32, no. 93 (2004), https:/ /doi.org/10.1080/1363981042000320143.

9 Amirul Hadi, Islam and State in Sumatra: A Study of Seventeenth-Century Aceh, Brill Leiden, vol. 53, 2004; Annabel Teh Gallop, "Gold, Silver and Lapis Lazuli: Royal Letters from Aceh in the 17th Century," First International Conference of Aceh Indian Ocean Studies 1998, no. March 1998 (2007).

${ }^{10}$ Henri Chambert-Loir, "Islamic Law in 17th Century Aceh," Archipel, no. 94 (2017), https://doi.org/10.4000/archipel.444; Ayang Utriza, "The Implementation of Sharia in Aceh as Based on the Code Extant in the Sultanate of Aceh from 15161688," Studia Islamika: Indonesian Journal for Islamic Studies 14, no. 3 (2007).

${ }^{11}$ Kamaruzzaman Kamaruzzaman, "Relasi Islam Dan Politik Dalam Sejarah Politik Aceh Abad 16-17,” Al-Tahrir: Jurnal Pemikiran Islam 16, no. 2 (2016), https:/ /doi.org/10.21154/al-tahrir.v16i2.494; Mohammad Hasan Anshori, "Linking Identity to Collective Action: Islam, History and Ethnicity in the Aceh Conflict," Studia Islamika 19, no. 1 (2012), https://doi.org/10.15408/sdi.v19i1.368. 
${ }^{12}$ Chiara Formichi, "Pan-Islam and Religious Nationalism: The Case of Kartosuwiryo and Negara Islam Indonesia," Indonesia, no. 90 (2010); S. Soebardi, "Kartosuwiryo and the Darul Islam Rebellion in Indonesia," Journal of Southeast Asian Studies 14, no. 1 (1983), https://doi.org/10.1017/S0022463400009024; Andi Rahman Alamsyah and Vedi R. Hadiz, "Three Islamist Generations, One Islamic State: The Darul Islam Movement and Indonesian Social Transformation," Critical Asian Studies 49, no. 1 (2017), https://doi.org/10.1080/14672715.2016.1260887.

${ }^{13}$ Salim, "'Sharia from below' in Aceh (1930s-1960s): Islamic Identity and the Right to Self determination with Comparative Reference to the Moro Islamic Liberation Front (MILF)," 95.

${ }^{14}$ Ibrahim Alfian, Aceh and The Holy War (Prang Sabil), Verandah of Violence, The Background to The Aceh Problem, 2006, 100.

${ }^{15}$ Edward Aspinall, "Separatism in Aceh: From Social Rebellion to Political Movement," in Social Activism in Southeast Asia, 2012, 40-55, https:/doi.org/ 10.4324/9780203100233.

${ }^{16}$ Kirsten Schulze, "The Free Aceh Movement (GAM)/ : Anatomy of a Separatist Organization,” Policy Studies, no. 2 (2004).

${ }^{17}$ Irine Hiraswari Gayatri, "Dynamics of Village Institution: The Gampong under Aceh ÿs Special,” Journal of Indonesian Social Sciences and Humanities 2 (2018), https://doi.org/10.14203/jissh.v2i0.33; Rodd McGibbon, "Local Leadership and the Aceh Conflict," in Verandah of Violence: The Background to the Aceh Problem, 2006; Jesse Hession Grayman, Mary Jo Delvecchio Good, and Byron J. Good, "Conflict Nightmares and Trauma in Aceh," Culture, Medicine and Psychiatry 33, no. 2 (2009), https://doi.org/10.1007/s11013-009-9132-8.

${ }^{18}$ Gunnar Stange and Roman Patock, "From Rebels to Rulers and Legislators: The Political Transformation of the Free Aceh Movement (GAM) in Indonesia," Southeast Asian Studies 29, no. 1 (2010): 95-120; Edward Aspinall and Harold Crouch, The Aceh Peace Process: Why It Failed, Policy Studies (Washington: the East-West Center Washington, 2003), https://sci-hub.tw/https://scholarspace.manoa.hawaii.edu/ handle/10125/3503\%0Ahttps://scholarspace.manoa.hawaii.edu/bitstream/10125/3503/ 1/PS001.pdf; Siti Ikramatoun, Firdaus Mirza Nusuary, and Khairul Amin, "GAM and Social Transformation, from A Rebellion into A Political Movement," Proceedings of the 1st Aceh Global Conference (AGC 2018), 2019, https://doi.org/10.2991/agc18.2019.35.

${ }^{19}$ Michelle Ann Miller, Rebellion and Reform in Indonesia: Jakarta's Security and Autonomy Policies in Aceh, 2008, https://doi.org/10.4324/9780203888193; Michelle Ann Miller, "What's Special about Special Autonomy in Aceh?," Verandah of Violence: The Background to the Aceh Problem, no. November (2006).

${ }^{20}$ Shane Joshua Barter, "Resources, Religion, Rebellion: The Sources and Lessons of Acehnese Separatism," Small Wars and Insurgencies 19, no. 1 (2008), https:// doi.org/10.1080/09592310801905769. 
${ }^{21}$ Michael Morfit, "The Road to Helsinki: The Aceh Agreement and Indonesia's Democratic Development," International Negotiation 12, no. 1 (2007), https://doi.org/ 10.1163/138234007X191939; Pieter Feith, "The Aceh Peace Process: Nothing Less than Success," Defense, 2006, 1-8.

${ }^{22}$ Kamaruzzaman Bustamam-Ahmad, "The Application of Islamic Law in Indonesia: The Case Study of Aceh," Journal of Indonesian Islam 1, no. 1 (2007), https://doi.org/10.15642/JIIS.2007.1.1.135-180; Hasnil Basri Siregar, " Islamic Law in a National Legal System: A Study on the Implementation of Shari'ah in Aceh, Indonesia," Asian Journal of Comparative Law 3 (2008), https://doi.org/10.1017/ s2194607800000156.

${ }^{23}$ Moch Nur Ichwan, "The Politics of Shariatization: Central Governmental and Regional Discourses of Shari'a Implementation in Aceh," in Islamic Law in Contemporary Indonesia: Ideas and Institutions, ed. Michael Feener and Mark Cammack (Boston: Islamic Legal Studies Program, Harvard University Press, 2007), 193-215.

${ }^{24}$ M Jafar, "Legitimasi Hukum Pemberlakuan Syari'at Islam Di Aceh: Tinjauan Yuridis, Sosiologis Dan Filosofis,” Ulumuna 19, no. 1 (June 29, 2015): 59-78, https:/ /doi.org/10.20414/ujis.v19i1.1250.

${ }^{25}$ Ichwan, "Official Ulema and the Politics of Re-Islamization: The Majelis Permusyawaratan Ulama, Sharatization and Contested Authority in Post-New Order Aceh,” 190.

${ }^{26}$ Abidin Nurdin, "Reposisi Peran Ulama dalam Penerapan Syariat Islam di Aceh,” Al-Qalam 18, no. 1 (2016), https://doi.org/10.31969/alq.v18i1.244.

${ }_{27}$ Amsori Amsori and Jailani Jailani, "Legislasi Qanun Jinayat Aceh dalam Sistem Hukum Nasional," Ar-Raniry: International Journal of Islamic Studies 4, no. 2 (2018), https://doi.org/10.20859/jar.v4i2.138.

${ }^{28}$ Human Rights Watch, "Aceh Under Martial Law: Inside the Secret War," Human Rights 15, no. 10 (2003); Fariba Zarinebaf, Policing Morality: Abuses in the Application of Sharia in Aceh, Indonesia, Living in the Ottoman Realm, 2016.

${ }^{29}$ Danial Danial, "Qanun Jinayah Aceh Dan Perlindungan HAM (Kajian YuridisFilosofis)," Al-Manahij: Jurnal Kajian Hukum Islam 6, no. 1 (1970), https://doi.org/ 10.24090/mnh.v6i1.590; "Konsepsi Pidana Hudud Dalam Qanun Jinayat Aceh-Indonesia Dan Brunei Darussalam,” Kanun: Jurnal Ilmu Hukum 19, no. 1 (2017), https:// doi.org/10.24815/kanun.v1911.6670; Dina Afrianty, Women and Sharia Law in Northern Indonesia: Local Women's NGOs and the Reform of Islamic Law in Aceh, 2015, https://doi.org/10.4324/9781315744568.

${ }^{30}$ Ma Theresa R. Milallos, "Muslim Veil as Politics: Political Autonomy, Women and Syariah Islam in Aceh," Contemporary Islam 1, no. 3 (2007), https://doi.org/ 10.1007/s11562-007-0028-5; Afrianty, Women and Sharia Law in Northern Indonesia: Local Women's NGOs and the Reform of Islamic Law in Aceh.

${ }^{31}$ Al Makin, "Islamic Acehnese Identity, Sharia, and Christianization Rumor: A Study of the Narratives of the Attack on the Bethel Church in Penauyong Banda Aceh,” Journal of Indonesian Islam 10, no. 1 (2016), https://doi.org/10.15642/JIIS.2016.10.1.1- 
36; Muhammad Ansor, Ismail Fahmi Arrauf, and Yaser Amri, "Under The Shadow of Sharia: Christian Muslim Relations from Acehnese Christian Experience," KOMUNITAS: International Journal of Indonesian Society and Culture 8, no. 1 (2016), https:// doi.org/10.15294/komunitas.v8i1.4966.

32 Bobby Rahman, "Pro Kontra Rancangan Peraturan Daerah Lhokseumawe tentang Larangan Duduk Secara Mengangkang Bagi Perempuan di Sepeda Motor," Jurnal Ilmu Politik Dan Komunikasi 3, no. 1 (2013).

${ }^{33}$ Eka Srimulyani, "Gender in Contemporary Acehnese Dayah: Moving beyond Docile Agency?," in Gender and Power In Indonesian Islam: Leaders, Feminists, Sufis and Pesantren Selves, 2013, https://doi.org/10.4324/9780203797518.

${ }^{34}$ Nirzalin Armia, “Teungku Dayah Dan Kekuasaan Panoptik,” Substantia 16, no. 1 (2014).

${ }^{35}$ Nirzalin Nirzalin, "Islamic Shari'a Politics and Teungku Dayah's Political Authority Crisis in Aceh," Journal of Government and Politics 3, no. 2 (August 1, 2012): 211-34, https://doi.org/10.18196/jgp.2012.0012.

${ }^{36}$ Fauzi Fauzi, "The Interactions of Madzhabs in Aceh: The Tripolar Typology," MIQOT: Jurnal Ilmu-Ilmu Keislaman 41, no. 1 (2017), https://doi.org/10.30821/ miqot.v41i1.327.

${ }^{37}$ Leena Avonious and Sehat Ihsan Shadiqin, Adat Dalam Dinamika Politik Aceh (Banda Aceh: ARTI-ICAIOS, 2011). 